\title{
Carbon monoxide apparent quantum yields and photoproduction in the Tyne estuary
}

\author{
A. Stubbins ${ }^{1, *}$, C. S. Law $^{2, * *}$, G. Uher ${ }^{1}$, and R. C. Upstill-Goddard ${ }^{1}$ \\ ${ }^{1}$ School of Marine Science and Technology, Newcastle University, UK \\ ${ }^{2}$ Plymouth Marine Laboratory, Plymouth, UK \\ *now at: Skidaway Institute of Oceanography, Savannah, Georgia \\ ** now at: National Institute of Water \& Atmospheric Research, Wellington, New Zealand
}

Received: 13 September 2010 - Published in Biogeosciences Discuss.: 13 October 2010

Revised: 28 February 2011 - Accepted: 2 March 2011 - Published: 18 March 2011

\begin{abstract}
Carbon monoxide (CO) apparent quantum yields (AQYs) are reported for a suite of riverine, estuarine and sea water samples, spanning a range of coloured dissolved organic matter (CDOM) sources, diagenetic histories, and concentrations (absorption coefficients). CO AQYs were highest for high CDOM riverine samples and almost an order of magnitude lower for low CDOM coastal seawater samples. CO AQYs were between 47 and $80 \%$ lower at the mouth of the estuary than at its head. Whereas, a conservative mixing model predicted only 8 to $14 \%$ decreases in CO AQYs between the head and mouth of the estuary, indicating that a highly photoreactive pool of terrestrial CDOM is lost during estuarine transit. The CDOM absorption coefficient ( $a$ ) at $412 \mathrm{~nm}$ was identified as a good proxy for CO AQYs (linear regression $r^{2}>0.8 ; n=12$ ) at all CO AQY wavelengths studied $(285,295,305,325,345,365$, and $423 \mathrm{~nm})$ and across environments (high CDOM river, low CDOM river, estuary and coastal sea). These regressions are presented as empirical proxies suitable for the remote sensing of $\mathrm{CO}$ AQYs in natural waters, including open ocean water, and were used to estimate CO AQY spectra and CO photoproduction in the Tyne estuary based upon annually averaged estuarine CDOM absorption data. A minimum estimate of annual $\mathrm{CO}$ production was determined assuming that only light absorbed by CDOM leads to the formation of $\mathrm{CO}$ and a maximum limit was estimated assuming that all light entering the water column is absorbed by $\mathrm{CO}$ producing photoreactants (i.e. that particles are also photoreactive). In this way, annual $\mathrm{CO}$ photoproduction in the Tyne was estimated to be between 0.99 and 3.57 metric tons of carbon per year, or
\end{abstract}

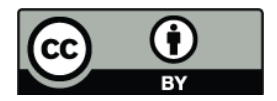

Correspondence to: A. Stubbins (aron.stubbins@skio.usg.edu)
0.004 to $0.014 \%$ of riverine dissolved organic carbon (DOC) inputs to the estuary. Extrapolation of $\mathrm{CO}$ photoproduction rates to estimate total DOC photomineralisation indicate that less than $1 \%$ of DOC inputs are removed via photochemical processes during transit through the Tyne estuary.

\section{Introduction}

Photochemistry, initiated when sunlight is absorbed by coloured dissolved organic matter (CDOM), represents an important pathway in the aquatic carbon-cycle. The net effects of dissolved organic matter (DOM) photodegradation include: the alteration of DOM bioavailability (Moran and Zepp, 1997; Mopper and Kieber, 2000; Miller et al., 2002); the bleaching of CDOM colour (Del Vecchio and Blough, 2002; Helms et al., 2008); and the production of a suite of photoproducts, including $\mathrm{CO}_{2}$ and $\mathrm{CO}$ (Valentine and Zepp, 1993; Miller and Zepp, 1995; Stubbins et al., 2006b). Photoproduction is the dominant source of $\mathrm{CO}$ in natural waters and results in the supersaturation of surface waters with $\mathrm{CO}$ and CO emission to the atmosphere (Conrad et al., 1982; Bates et al., 1995; Stubbins et al., 2006a).

Precise and accurate quantification of $\mathrm{CO}$ photoproduction is facilitated by sensitive analytical techniques and low background $\mathrm{CO}$. Consequently, $\mathrm{CO}$ has been suggested as a useful proxy from which other, less easily quantified photoreaction rates can be extrapolated. For instance, the ratio of dissolved inorganic carbon:CO photoproduction is approximately 15:1 (Miller and Zepp, 1995; Gao and Zepp, 1998). CO has also emerged as a key tracer for use in testing and tuning models of mixed layer processes (Kettle, 2005; Doney et al., 1995; Najjar et al., 1995) and for the exploration of photochemical mechanisms (Stubbins et al., 2008). As quantitatively

Published by Copernicus Publications on behalf of the European Geosciences Union. 
the second largest product of CDOM photomineralization (Miller and Zepp, 1995; Mopper and Kieber, 2001), CO photoproduction is also a significant term in the global carboncycle.

Calculating the rate of a photoreaction in the natural environment requires knowledge of its spectral efficiency or quantum yield (QY). The QY is defined as the number of moles of product formed or reactant lost per mole of photons (einsteins; E) absorbed at a given wavelength $(\lambda)$. If the molar absorption coefficient and concentration of a reactant are known, true reaction QYs can be calculated. However, as CDOM chromophores are not well characterized, QYs are usually normalized to the total absorbance of dissolved constituents, providing an apparent quantum yield (AQY). AQYs for photoreactions involving CDOM display near-monotonic decreases with increasing wavelength between 270 and $600 \mathrm{~nm}$ (Valentine and Zepp, 1993), necessitating the determination of AQY spectra to account for this wavelength dependence.

CO AQY spectra have been reported for a variety of waters. Most studies report CO AQY spectra either exclusively for fresh water (Valentine and Zepp, 1993; Gao and Zepp, 1998) or exclusively for seawater (Kettle, 1994; Ziolkowski and Miller, 2007; Zafiriou et al., 2003), finding relatively minor, unexplained variations between samples. However, if data from different environments are compared, clear variations can be seen between marine and freshwater CO AQY spectra (Stubbins, 2001; Zhang et al., 2006; Xie et al., 2009; White et al., 2010). The most noticeable of these is that values for seawater AQYs are around 5-10 times lower than those for freshwaters. These variations have been ascribed to a combination of qualitative relationships, including a reduction in the concentration of aromatic chromophores, as indicated by lower CDOM light absorption at higher salinities, differences in the chemistry of terrestrial versus marine derived DOM, and a reduction in CO AQY with increasing irradiance dose (Stubbins, 2001; Zhang et al., 2006).

In the open ocean CO AQYs and CDOM levels are relatively constant allowing $\mathrm{CO}$ photoproduction to be reasonably well constrained (30-90 $\mathrm{Tg} \mathrm{CO}-\mathrm{C} \mathrm{yr}^{-1}$; Zafiriou et al., 2003; Stubbins et al., 2006b; Fichot and Miller, 2010). However, variability in CDOM concentration and reactivity complicates predicting photoreaction rates in terrestrially influenced waters. Here we report variations in CO AQYs across strong gradients in CDOM concentration, source and reaction history in the Tyne estuary, England, and in four British rivers (North Tyne, South Tyne, Tay and Tamar). A resulting relationship between CDOM light absorption and CO AQYs is recommended for use in predicting the photoreactivity of natural waters using in situ or remotely sensed measurements of CDOM absorption coefficients. This rationale is similar to that employed in previous studies (Stubbins, 2001; Xie et al., 2009; Fichot and Miller, 2010). This approach to predicting CO AQYs is used to estimate annual CO photoproduction within the Tyne estuary.

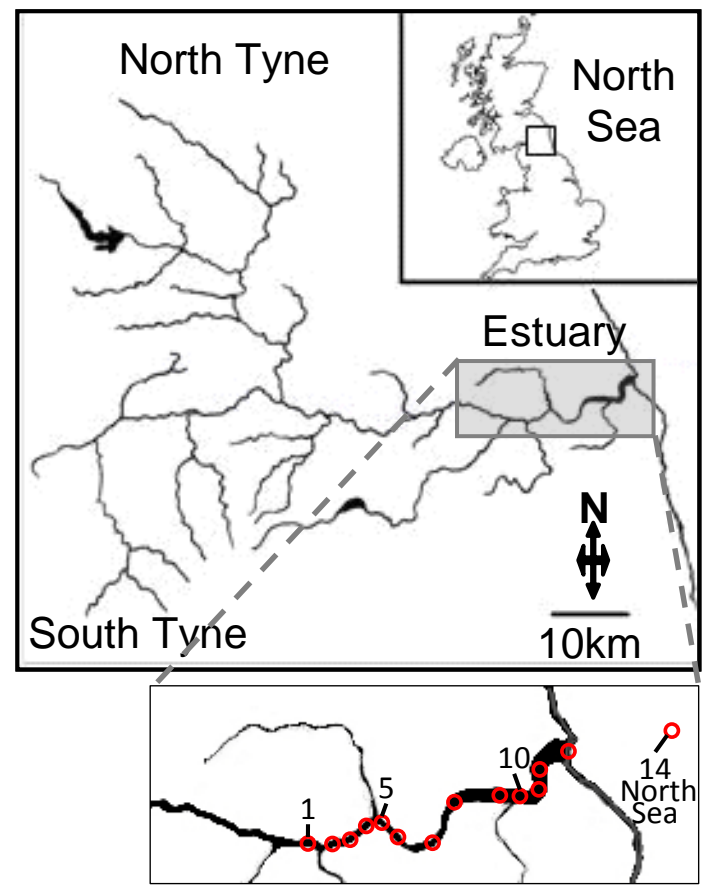

Fig. 1. Tyne catchment with North Tyne, South Tyne and Tyne estuary marked. Inset: map of UK showing location of the Tyne catchment. Red circles indicate the locations of stations described in Table 1.

\section{Methods}

\subsection{Field site}

The River Tyne (Fig. 1), North East England, has two main tributaries, the North and South Tyne. Inputs of organic carbon from thick $(\leq 10 \mathrm{~m})$ blanket peats give the North Tyne high DOC concentrations (mean: $1099 \mu \mathrm{M}$; Spencer et al., 2007), whereas, the South Tyne drains predominantly moorland covered limestone and has lower DOC concentrations (mean: $456 \mu \mathrm{M}$; Spencer et al., 2007). The catchment is mainly pastoral below the confluence of the two tributaries, with some arable and industrial land. DOC concentrations at the head of the estuary range from $\sim 600-2300 \mu \mathrm{M}$ (mean $\sim 1200 \mu$ M; Spencer et al., 2007). These high inputs of terrestrial DOC dominate over anthropogenic point sources, the latter being confined to the seaward end of the estuary (Spencer et al., 2007). The estuary is $35 \mathrm{~km}$ long, macrotidal and partially mixed, with an average annual residence time of $\sim 12$ days (Watts-Rodrigues, 2003) and a mean spring tidal range of 0.7-5.0 $\mathrm{m}$ (www.PortofTyne.co.uk). The estuary and lower river were canalized in the latter half of the 19th century, with islands removed and meanders straightened. In 1850, the Tyne Improvement Commission began dredging the estuary, stretching $16 \mathrm{~km}$ inland. Today the river is navigable $24 \mathrm{~km}$ inland, which includes all estuarine sampling sites in the current study (Stations 1-14). Dredging 
Table 1. Tyne estuary station numbers, geographical coordinates, surface areas, residence times, volumes, mean annual salinity and mean annual coloured dissolved organic matter absorption coefficient at $412 \mathrm{~nm}$. Standard errors are reported for salinity and CDOM $a_{412}$ data, together with sampling number, $n$, reported in parenthesis. Data were collected during 11 transects of the Tyne estuary which took place between November 1998 and April 2001.

\begin{tabular}{lcccccc}
\hline Station & $\begin{array}{c}\text { Lat }(\mathrm{N}): \\
\text { Long }(\mathrm{W})\end{array}$ & $\begin{array}{c}\text { Surface } \\
\text { Area }\left(\mathrm{km}^{2}\right)\end{array}$ & $\begin{array}{c}\text { Residence } \\
\text { Time }\left(\mathrm{d}^{-1}\right)\end{array}$ & $\begin{array}{c}\text { Volume } \\
\left(10^{6} \mathrm{~m}^{3}\right)\end{array}$ & $\begin{array}{c}\text { Salinity } \\
(-)\end{array}$ & $\begin{array}{c}\text { CDOM } a_{412} \\
\left(\mathrm{~m}^{-1}\right)\end{array}$ \\
\hline 1 & $54.9650: 1.6833$ & 0.85 & 0.22 & 1.263 & $0.4 \pm 0.3(5)$ & $18.1 \pm 0.8(5)$ \\
2 & $54.9633: 1.6617$ & 0.40 & 0.20 & 1.149 & $0.6 \pm 0.6(4)$ & $17.2 \pm 1.0(4)$ \\
3 & $54.9583: 1.6350$ & 0.38 & 0.21 & 1.206 & $1.2 \pm 0.9(5)$ & $17.0 \pm 1.1(5)$ \\
4 & $54.9667: 1.6117$ & 0.31 & 0.18 & 1.085 & $2.0 \pm 1.4(5)$ & $15.8 \pm 0.7(5)$ \\
5 & $54.9700: 1.5884$ & 0.13 & 0.06 & 0.437 & $6.0 \pm 1.3(14)$ & $14.5 \pm 1.0(14)$ \\
6 & $54.9650: 1.5733$ & 0.22 & 0.16 & 1.097 & $7.0 \pm 1.8(10)$ & $13.4 \pm 1.2(10)$ \\
7 & $54.9616: 1.5400$ & 0.53 & 0.41 & 2.915 & $7.4 \pm 2.0(10)$ & $12.5 \pm 1.1(10)$ \\
8 & $54.9833: 1.5283$ & 0.70 & 0.61 & 4.882 & $10.4 \pm 2.1(4)$ & $11.0 \pm 1.6(4)$ \\
9 & $54.9867: 1.4850$ & 0.44 & 0.34 & 2.851 & $11.4 \pm 5.0(10)$ & $7.1 \pm 2.9(10)$ \\
10 & $54.9883: 1.4733$ & 0.31 & 0.23 & 2.075 & $13.5 \pm 2.2(5)$ & $7.7 \pm 1.3(5)$ \\
11 & $54.9867: 1.4600$ & 0.62 & 0.52 & 4.982 & $14.4 \pm 3.9(5)$ & $7.7 \pm 1.8(5)$ \\
12 & $55.0000: 1.4417$ & 0.44 & 0.35 & 3.814 & $17.0 \pm 4.3(10)$ & $6.7 \pm 1.9(10)$ \\
13 & $55.0130: 1.4101$ & 0.99 & 0.78 & 8.734 & $17.6 \pm 2.7(10)$ & $7.1 \pm 1.2(10)$ \\
14 & $55.0467: 1.3063$ & 0.85 & 0.56 & 8.303 & $21.7 \pm 2.4(11)$ & $5.2 \pm 1.0(11)$ \\
& & & & & & \\
\hline
\end{tabular}

maintains depths of $9.1 \mathrm{~m}$ below Chart Datum throughout most of the estuary (Stations 4-12; Table 1) and $12.1 \mathrm{~m}$ below Chart Datum below the Riverside Quay (Station 13 and 14; Table 1) (www.PortofTyne.co.uk). The canalized nature of the lower river and estuary, along with other factors including the absence of substantial areas of tidal flooding and drainage, make the Tyne a near-ideal system for determining the impacts of estuarine processes upon CDOM photoreactivity. In addition, the predominance of peat derived DOC in the Tyne makes it representative of most UK catchments (Hope et al., 1997) and northern peatlands generally.

Samples from the River Tamar (South West England) and the River Tay (South East Scotland) are also included. The Tamar's catchment is dominated by moorland with some contribution from deciduous woodland and hill farms. DOC concentrations in the River Tamar are lower than for the peat dominated Tyne, reaching a maximum of about $480 \mu \mathrm{M}$ (Miller, 1999). The Tay is one of the least contaminated rivers in Europe (Sholkovitz, 1979) and the largest river in the UK based upon mean annual discharge (Maitland and Smith, 1987). To our knowledge, no DOC data exists for the Tay. Like the Tamar, the catchment is dominated by moorland, with minimal arable $(8 \%)$, forestry $(5 \%)$ and urban (1\%) land (Bryant and Gilvear, 1999). Soils are thin and underlain by metamorphic rocks (Bremner, 1939). Inclusion of samples from these rivers, together with those from the moorland/limestone dominated South Tyne and the coastal North Sea, give the data set relevance beyond peat dominated systems.
Samples for the determination of CO AQYs were collected from the Tyne estuary and North Sea onboard R/V Bernicia (April 2001), from the Tamar onboard R/V Tamaris (April 2001), and from the Tay, North Tyne and South Tyne from riverbanks (May 2001). In addition, samples for salinity and CDOM absorbance analyses were collected from the Tyne estuary during 11 axial transects conducted between November 1998 and April 2001, again on R/V Bernicia. All samples were collected using a pre-cleaned (10\% hydrochloric acid, ultrapure laboratory water from a Millipore Q185 system hereafter referred to as Milli-Q) and sample rinsed polyethylene bucket and placed in similarly cleaned high density polyethylene carboys. Samples were transported in the dark and then $0.1 \mu \mathrm{m}$ filtered through a Millipore POLYCAP 150 TC filter capsule which had been flushed with acetonitrile, Milli-Q, and sample. Filtration was carried out in a darkroom (lit using a red photographic "safe" light) within $24 \mathrm{~h}$ of collection. Samples were stored refrigerated in complete darkness for $<2$ weeks before use.

\subsection{Monochromatic irradiations}

Further sample processing and irradiations were conducted in the temperature controlled darkroom. Samples were allowed to reach room temperature and then re-filtered immediately prior to irradiation $(0.1 \mu \mathrm{m})$; the latter in order to remove potential bacterial re-growth that could have led to microbial $\mathrm{CO}$ oxidation and an underestimation of $\mathrm{CO}$ AQYs. No DOM precipitation was noticed in between filterings and CDOM absorption coefficients remained constant 
(less than $0.5 \%$ variations at $300 \mathrm{~nm}$ ), indicating negligible losses of CDOM due to repeated filtering or microbial activity. Samples were then bubbled with CO scrubbed zerograde air (Hopcalite scrubber) for $\geq 1 \mathrm{~h}$ to reduce background $\mathrm{CO}$ and ensure consistent pre-irradiation levels of other dissolved gases. The same bottle of zero-grade air was used throughout. Volatile $\mathrm{DOM}, \mathrm{pH}$ and $p \mathrm{CO}_{2}$, which may have had an influence on sample $\mathrm{CO}$ photoproduction, were not measured pre- or post-purging. Purged sample was introduced through clean Tygon tubing into a quartz cell (diameter $=17.3 \mathrm{~mm}$, length $=200 \mathrm{~mm}$, volume $=84 \mathrm{~mL}$ ) which had been pre-rinsed with hydrochloric acid (0.1 M), Milli$\mathrm{Q}$ and sample. The cell was flushed and allowed to overflow before it was capped with gas-tight nylon SwageLok fittings. The cell was then placed in the light beam of a monochromator ( $25 \mathrm{~cm}$ grating monochromator, Model 77200 ; Oriel Instruments) with a $1 \mathrm{~kW} \mathrm{Hg}$-Xe light source and with the bandpass set to $5 \mathrm{~nm}$. Irradiations were run at $25^{\circ} \mathrm{C}$ and at the following wavelengths: 285, 295, 305, 325, 345, 365 and $423 \mathrm{~nm}$. Photon flux into the irradiation cell was determined using potassium ferrioxalate liquid-phase chemical actinometry (Calvert and Pitts, 1966). Thirty minute irradiations were routinely used for determining CO AQYs. However, due to low production rates, the North Sea water sample was irradiated for $60 \mathrm{~min}$ at 365 and $423 \mathrm{~nm}$. For each irradiated sample an aliquot of filtered water was placed in a $60 \mathrm{~mL}$ gas tight crimp top vial. Vials were prepared and filled as described above for the irradiation cell and were then incubated at $25^{\circ} \mathrm{C}$ in the dark to provide dark controls for each irradiation. As with the irradiated samples, these dark controls were transferred to the vials using Tygon tubing. Tygon can introduce CO contamination. However, in the current study any contamination from the Tygon was minor as dark $\mathrm{CO}$ concentrations were universally low $(<2 \mathrm{nM})$.

\subsection{Ultraviolet-visible absorption spectra}

CDOM absorption coefficient spectra (250 to $800 \mathrm{~nm}$ ) were determined using a $1 \mathrm{~cm}$ quartz cuvette and a scanning UVvisible, double-beam, spectrophotometer (Kontron, Uvicon 923) with Milli-Q water as a reference beam blank. CDOM spectra were corrected for offsets due to scattering and instrument drift by subtraction of the average absorbance between 700 and $800 \mathrm{~nm}$. Data output from the spectrophotometer were in the form of dimensionless absorbance or optical density (OD) and were converted to the Napierian absorption coefficient, $a\left(\mathrm{~m}^{-1}\right.$; Hu et al., 2002). Light attenuation spectra for unfiltered samples were also determined using the above method. An approximation of light absorption spectra for coloured particulate material (CPM) was then determined by subtracting the filtered-water CDOM absorbance spectra from the light attenuation spectra of unfiltered samples, and then zeroing the resultant spectra at longer wavelengths by subtraction of the average absorbance between 700 and $800 \mathrm{~nm}$. The spectra were zeroed between 700 and $800 \mathrm{~nm}$ as natural aquatic particles exhibit negligible absorbance at these wavelengths (Babin and Stramski, 2002), such that it is reasonable to attribute the attenuation at these wavelengths to scattering. The resultant PCM spectra should still be regarded as over-estimates of CPM absorbance as they include contributions to light attenuation from additional scattering by particles at shorter wavelengths that can be significant (Preisendorfer, 1976).

\subsection{Carbon monoxide}

Dark and light CO samples were collected and processed immediately after irradiation. Differences between darks and lights were used to determine the amount of $\mathrm{CO}$ produced during irradiation. In the darkroom, crimp top vials $(60 \mathrm{~mL})$ were flushed with sample before sealing with Teflon faced butyl septa. CO scrubbed carrier gas was introduced through the vial septa via a needle to create a $25 \mathrm{~mL}$ headspace. Following 30 min dark equilibration using a wrist action shaker, CO scrubbed water was introduced to the vial through a syringe. A second syringe was used to collect 15 to $20 \mathrm{~mL}$ of the displaced headspace gas. The CO mixing ratio within the headspace was measured using a reduction gas detector with UV-photometer (RGD2, Trace Analytical, Menlo Park, USA) following separation by gas chromatography (Stubbins et al., 2006a). The RGD2 sensitivity is quoted at \pm 1 ppbv CO with greater than $98 \%$ reproducibility (Trace Analytical) and has been shown to be linear over a wide range of $\mathrm{CO}$ concentrations (0 to $900 \mathrm{ppbv}$; Sjöberg, 1999). Precision of this method when measuring standards was better than $\pm 1 \%$. Mean percentage standard errors for sample replicates were $\leq 2 \%$. A method blank was determined by irradiating $\mathrm{CO}$ purged MilliQ water. CO photoproduction was undetectable in this blank. The blank was transferred to the irradiation cell using Tygon tubing and did not cause any measurable CO contamination.

\subsection{Calculation of apparent quantum yields}

CO AQYs were calculated following Zafiriou et al. (2003) as the moles of $\mathrm{CO}$ produced per mole of photons absorbed by CDOM during each irradiation.

\section{Results and discussion}

\subsection{Apparent quantum yields}

Freshwater and seawater CO AQY spectra (Fig. 2) exhibited near log-linear decreases with increasing wavelength. CO AQYs at a given wavelength fell rapidly with increasing salinity, with AQYs at the head of the Tyne estuary being 2 to 6 times higher than at the mouth (see Fig. 3 for AQYs at $325 \mathrm{~nm}$ and Table 2 for all wavelengths). These results are consistent with previously published CO AQY spectra from fresh (Valentine and Zepp, 1993; Kettle, 1994; Gao 


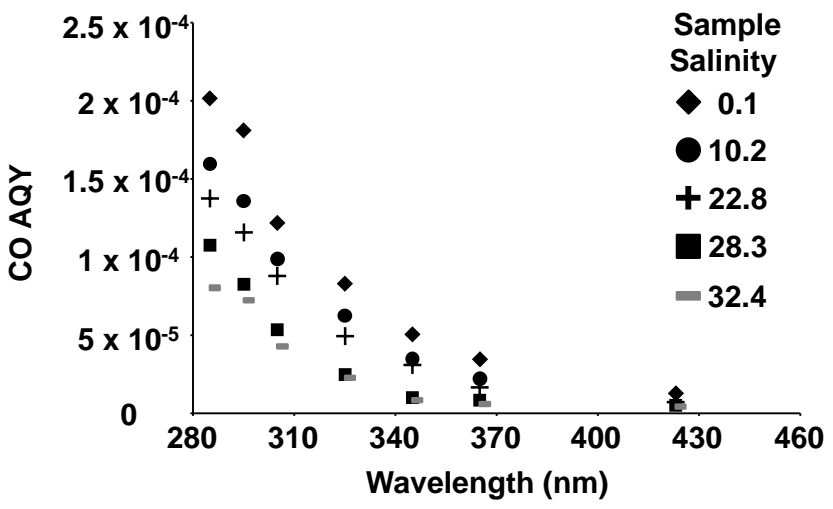

Fig. 2. Carbon monoxide apparent quantum yield spectra for the Tyne estuary.

and Zepp, 1998) and marine (Ziolkowski and Miller, 2007; Zafiriou et al., 2003) waters. Similar salinity dependence of CO AQYs has also been observed in other estuaries (Zhang et al., 2006; Xie et al., 2009; White et al., 2010). The CO photoproduction efficiency from simple CDOM analogues has been shown to decrease when electron donating groups are substituted with electron withdrawing groups around the aromatic ring (Stubbins et al., 2008). It is therefore possible that similar changes in the substituent chemistry of aromatic chromophores occur across the freshwater-marine interface and drive the observed trends in CO AQYs.

\subsection{Endmember mixing}

A simple 2 component mixing model was employed to investigate the quantitative and qualitative variations in CO AQYs in the Tyne estuary. This model predicted CO AQYs based on the conservative mixing of two endmembers - Tyne water from Scotswood Bridge at the head of the estuary (salinity: 0.1 ) and coastal North Sea water (salinity: 32.4; Table 2). These two endmembers were those from the 9 April 2001 transect during which samples for all estuarine CO AQYs were collected. Salinity and CDOM absorbance at $325 \mathrm{~nm}$ of samples from the 9 April 2001 transect are reported in Table 3, these values were used to predict the conservative mixing of CO AQYs at $325 \mathrm{~nm}$ as represented in Fig. 3. At a specific estuarine station and wavelength the proportion of $a \mathrm{CDOM}$ predicted to be riverine assuming conservative mixing, $\left(\mathrm{R}-a \mathrm{CDOM}_{\lambda} @ \mathrm{St}_{n}\right)$ was calculated as:

$$
\begin{gathered}
\mathrm{R}-a \mathrm{CDOM}_{\lambda} @ \mathrm{St}_{n}=\left(\mathrm{St}_{n}-a \mathrm{CDOM}_{\lambda}-\mathrm{NS}-a \mathrm{CDOM}_{\lambda}\right. \\
\left.\cdot \mathrm{St}_{n}-\mathrm{Sal} / \mathrm{NS}-\mathrm{Sal}\right) / \mathrm{St}_{n}-a \mathrm{CDOM}_{\lambda}
\end{gathered}
$$

where $\mathrm{St}_{n}-a \mathrm{CDOM}_{\lambda}$ is $a \mathrm{CDOM}$ at wavelength, $\lambda$, measured at station $n$; NS- $a \mathrm{CDOM}_{\lambda}$ is $a \mathrm{CDOM}_{\lambda}$ of North Sea water; $\mathrm{St}_{n}$-Sal is measured salinity at station $n$; and NS-Sal is North Sea salinity (in this transect 32.4). CO AQY at a specific station and wavelength $\left(\mathrm{St}_{n}-\mathrm{CO} \mathrm{AQY}{ }_{\lambda}\right)$ was then calculated as:

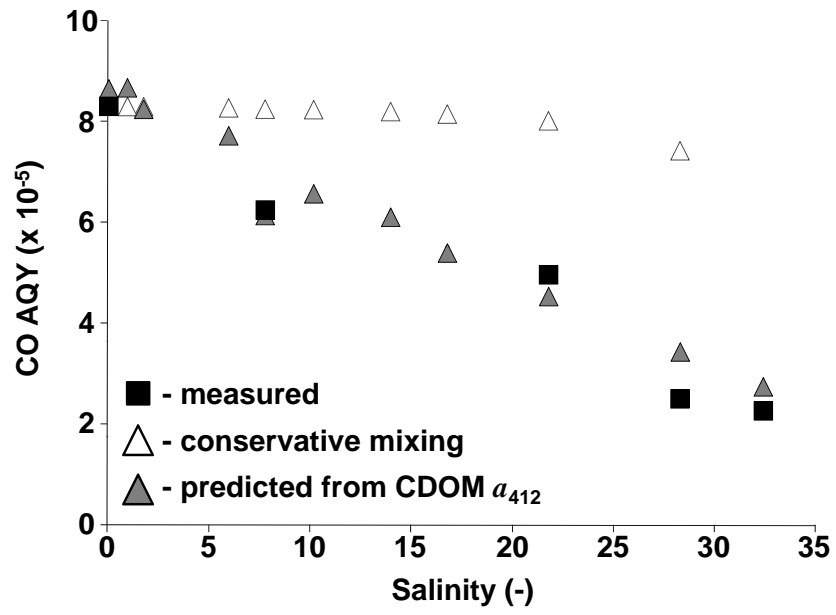

Fig. 3. Measured and modelled carbon monoxide apparent quantum yields (CO AQYs) at $325 \mathrm{~nm}$ versus salinity in the Tyne estuary on the 9 April 2001. Grey fill squares are measured values. No fill triangles are values predicted based upon a conservative mixing model of the river water and marine endmembers of the Tyne estuary. Fill triangles are values predicted using in situ CDOM $a_{412}$ as a proxy for CO AQYs.

$$
\begin{gathered}
\mathrm{St}_{n}-\mathrm{CO} \mathrm{AQY} \\
+\left(1-\mathrm{St}_{n}-\mathrm{St}_{n}-\mathrm{RDOM}_{\lambda}\right) \cdot \mathrm{CDOM}_{\lambda} \cdot \mathrm{RS}-\mathrm{CO} \mathrm{AQY} \mathrm{AQY}_{\lambda} \\
+
\end{gathered}
$$

where R-CO AQY $\lambda$ and NS-CO AQY $\lambda$ are wavelength specific CO AQYs determined for Tyne River and North Sea water, respectively.

The above conservative mixing model predicts an $11 \%$ decrease in CO AQYs at $325 \mathrm{~nm}$ between the head of the estuary and salinity 28.3 (station "Tyne plume", Fig. 3, Table 2). However, actual reductions in CO AQYs were $70 \%$ at $325 \mathrm{~nm}$ (Fig. 3; results at $325 \mathrm{~nm}$ are broadly consistent with other wavelengths), indicating non-conservative decreases in CDOM photoreactivity in the estuary. This observation is consistent with the addition of low photoreactivity CDOM, removal of high photoreactivity CDOM, or some combination of the two, during estuarine mixing. Localised inputs of CDOM can be observed in the immediate proximity of the Howdon wastewater plant (salinity $\sim 12$; Fig. 6) and the lower estuary where there is a considerable amount of shipping traffic (salinity 15-17; Fig. 6). However, these anthropogenic inputs, like those from estuarine mudflats, tributaries and primary production, are minor compared to riverine inputs of DOC, which dominate in the estuary (Ahad et al., 2008). As other inputs of CDOM seem insufficient to impact CDOM photoreacticity, we consider the removal of highly photoreactive CDOM to be the most likely explanation for reduced CO AQYs within the estuary. We previously reported an average $35 \%$ removal of Tyne CDOM $a$ at $350 \mathrm{~nm}$ during estuarine mixing, possibly due to a combination of CDOM adsorptive removal and flocculation at low salinity (Uher et al., 2001) and/or its progressive photochemical and 
Table 2. Carbon monoxide apparent quantum yields for Tyne estuary samples of varying salinity (all samples from 9 April 2001).

\begin{tabular}{|c|c|c|c|c|c|c|c|c|}
\hline \multirow[b]{2}{*}{$\begin{array}{l}\text { Station Name } \\
\text { (\# in Table 1) }\end{array}$} & \multirow[b]{2}{*}{ Salinity } & \multicolumn{7}{|c|}{ Wavelength (nm) } \\
\hline & & 285 & 295 & 305 & 325 & 345 & 365 & 423 \\
\hline $\begin{array}{l}\text { Scotswood } \\
\text { Bridge (1) }\end{array}$ & 0.08 & $2.02 \times 10^{-04}$ & $1.81 \times 10^{-04}$ & $1.22 \times 10^{-04}$ & $8.30 \times 10^{-05}$ & $5.06 \times 10^{-05}$ & $3.46 \times 10^{-05}$ & $1.28 \times 10^{-05}$ \\
\hline $\begin{array}{l}\text { Near } \\
\text { Howdon (9) }\end{array}$ & 10.2 & $1.60 \times 10^{-04}$ & $1.36 \times 10^{-04}$ & $9.87 \times 10^{-05}$ & $6.25 \times 10^{-05}$ & $3.48 \times 10^{-05}$ & $2.22 \times 10^{-05}$ & no data \\
\hline $\begin{array}{l}\text { Tynemouth } \\
\text { Piers (12) }\end{array}$ & 21.8 & $1.37 \times 10^{-04}$ & $1.16 \times 10^{-04}$ & $8.78 \times 10^{-05}$ & $4.96 \times 10^{-05}$ & $3.09 \times 10^{-05}$ & $1.68 \times 10^{-05}$ & $7.19 \times 10^{-06}$ \\
\hline $\begin{array}{l}\text { Tyne Plume } \\
\text { (13) }\end{array}$ & 28.3 & $1.08 \times 10^{-04}$ & $8.25 \times 10^{-05}$ & $5.35 \times 10^{-05}$ & $2.50 \times 10^{-05}$ & $1.00 \times 10^{-05}$ & $8.62 \times 10^{-06}$ & $5.35 \times 10^{-06}$ \\
\hline $\begin{array}{l}\text { North Sea } \\
\text { (14) }\end{array}$ & 32.4 & $8.04 \times 10^{-05}$ & $7.26 \times 10^{-05}$ & $4.30 \times 10^{-05}$ & $2.27 \times 10^{-05}$ & $8.57 \times 10^{-06}$ & $6.01 \times 10^{-06}$ & $4.28 \times 10^{-06}$ \\
\hline
\end{tabular}

microbial degradation throughout the estuary. Of these possible removal processes only photodegradation is known to reduce CO AQYs for CDOM (Stubbins, 2001; Zhang et al., 2006). Further work is thus required to determine whether microbial degradation, flocculation or adsorption onto suspended matter alter CDOM photoreactivity and to quantify their effects, along with that of photodegradation, upon the photoreactivity of riverine CDOM exported to the oceans.

\subsection{Absorption coefficient versus apparent quantum yields}

Considering the above results, a simple conservative mixing model cannot be used to predict variations in CO AQY in the Tyne estuary and a more robust approach is therefore necessary. Our initial data analysis revealed correlations between CO AQYs and sample CDOM absorption coefficients at various wavelengths. We subsequently selected the CDOM absorbance coefficient at $412 \mathrm{~nm}$ (CDOM $\left.a_{412}\right)$ as a suitable proxy for three reasons: (1) CDOM $a_{412}$ is readily measurable in situ; (2) there is a large historical CDOM data set for the Tyne and other aquatic systems; and (3) robust estimates of CDOM $a_{412}$ can be retrieved from SeaWiFS (http://oceancolor.gsfc.nasa.gov/SeaWiFS) and MODIS (http://modis.gsfc.nasa.gov) datasets.

Considering only samples from the Tyne, linear regressions of CO AQYs at all wavelengths versus CDOM $a_{412}$ had $r^{2}$ values greater than 0.8 , indicating that CDOM $a_{412}$ is a useful proxy for CO AQY in the North Tyne, lower River Tyne and Tyne estuary (Fig. 4), which show high levels of peat derived DOC. When the four samples from non-peat dominated systems (the South Tyne, River Tamar, River Tay, and coastal North Sea) are included in the analysis it can be seen that CO AQYs in the moorland dominated South Tyne and Tamar Rivers both lie above the regression line for the entire sample set (Fig. 4), indicating that perhaps moorland derived CDOM has higher CO AQYs than that from peatland catchments. However, the sample from the River Tay lies right on the regression line and is also from a moorland catchment. Therefore, the current dataset is too small to draw meaningful conclusions about how CO AQYs might vary with CDOM source.

Despite the minor variations mentioned above, adding the data points from the four non-peatland sites to the regression resulted in an $r^{2}$ that remained $>0.8$ for all wavelengths, excepting $285 \mathrm{~nm}$, for which $r^{2}$ was 0.77 (Fig. 4 and additional details in caption), indicating that CDOM $a_{412}$ is a suitable proxy for CO AQYs in marine waters and in peat and non-peat carbon dominated rivers. The equations presented here, along with those reported by Xie et al. (2009), provide a means of predicting environmental CO AQY spectra from remotely sensed optical properties of natural water bodies. Similar equations provided in Stubbins (2001) relate CO AQYs to CDOM light absorption at the CO AQY irradiation wavelength and were later used to derive a $\mathrm{CO} A Q Y$ spectrum based upon open ocean CDOM light absorption (Stubbins et al., 2006b). This spectrum was representative of other CO AQY spectra measured directly by irradiation of seawater samples (Ziolkowski and Miller, 2007; Zafiriou et al., 2003). As part of the current study, we recalculated the open ocean CO AQY spectrum using the open ocean CDOM absorbance data at $412 \mathrm{~nm}$ from Stubbins et al. (2006b) along with the equations in the caption to Fig. 4. The derived AQY spectrum is again representative of measured open ocean $\mathrm{CO}$ AQY spectra (Fig. 5), demonstrating the robustness of using CDOM light absorption coefficients at $412 \mathrm{~nm}$ to predict riverine, estuarine and open ocean CO AQYs. 

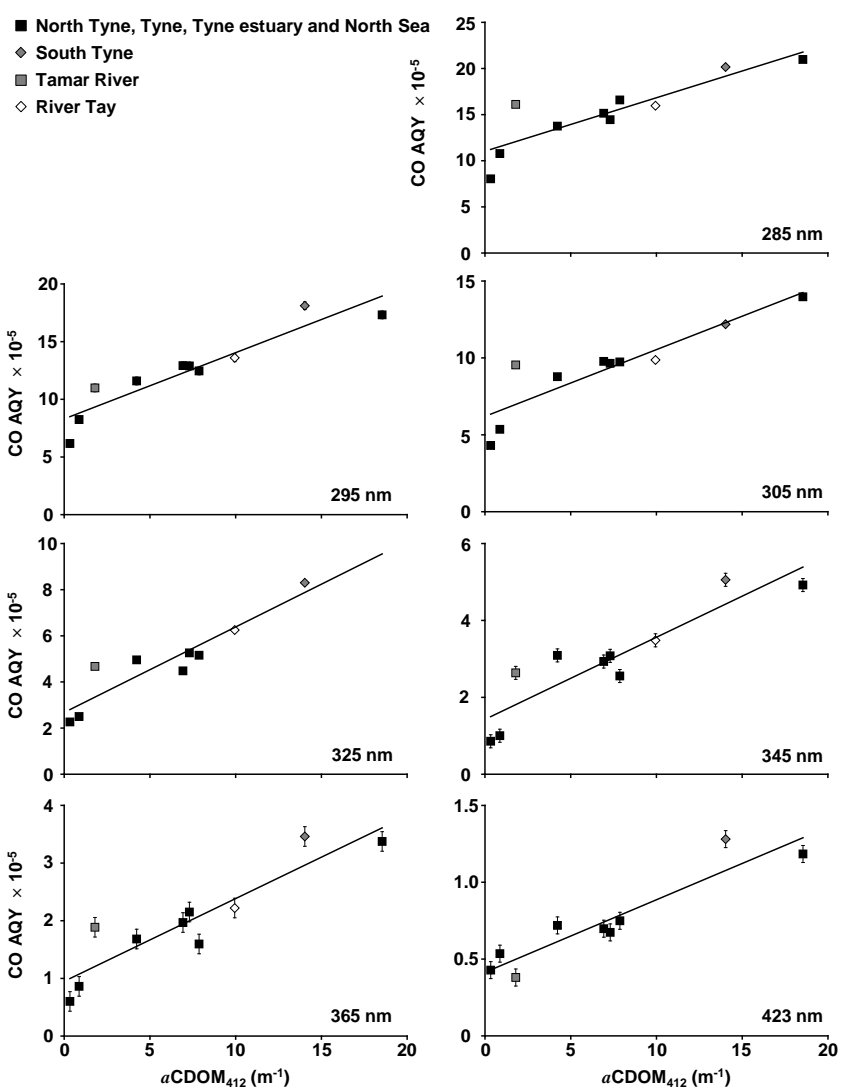

Fig. 4. Measured riverine: estuarine and coastal seawater carbon monoxide apparent quantum yields (CO AQYs) versus sample absorption coefficient at $412 \mathrm{~nm}\left(\mathrm{CDOM} a_{412}\right)$. Black fill squares are from the North Tyne: River Tyne: Tyne estuary and coastal North Sea (North East England); grey fill diamond is from the South Tyne (North East England); grey fill square is from the Tamar River (South West England); and no fill diamond is from the River Tay (South East Scotland). Straight lines are linear regressions of all data: where $\mathrm{CO} \mathrm{AQY}{ }_{\lambda}=y_{0}+m \times a_{412}: y_{0}$ is the $y$-intercept (CO AQY) and $m$ the slope of linear regressions of CO AQY at wavelength: $\lambda$ : against sample CDOM absorption coefficient at $412 \mathrm{~nm}$ $\left(a_{412}\right)$. Statistics for the curves are as follows:

\begin{tabular}{cccccc}
\hline $\begin{array}{c}\text { Wavelength } \\
(\mathrm{nm})\end{array}$ & $y_{0} \times 10^{-6}$ & $m \times 10^{-6}$ & $r^{2}$ & $p$ & $n$ \\
\hline 285 & 110.3 & 5.796 & 0.77 & 0.0009 & 10 \\
295 & 83.05 & 5.740 & 0.87 & $<0.0001$ & 10 \\
305 & 61.98 & 4.341 & 0.81 & 0.0004 & 10 \\
325 & 26.77 & 3.706 & 0.86 & 0.0003 & 9 \\
345 & 14.26 & 2.137 & 0.83 & 0.0003 & 10 \\
365 & 9.49 & 1.435 & 0.83 & 0.0002 & 10 \\
423 & 4.14 & 0.472 & 0.88 & 0.0002 & 9 \\
\hline
\end{tabular}

www.biogeosciences.net/8/703/2011/

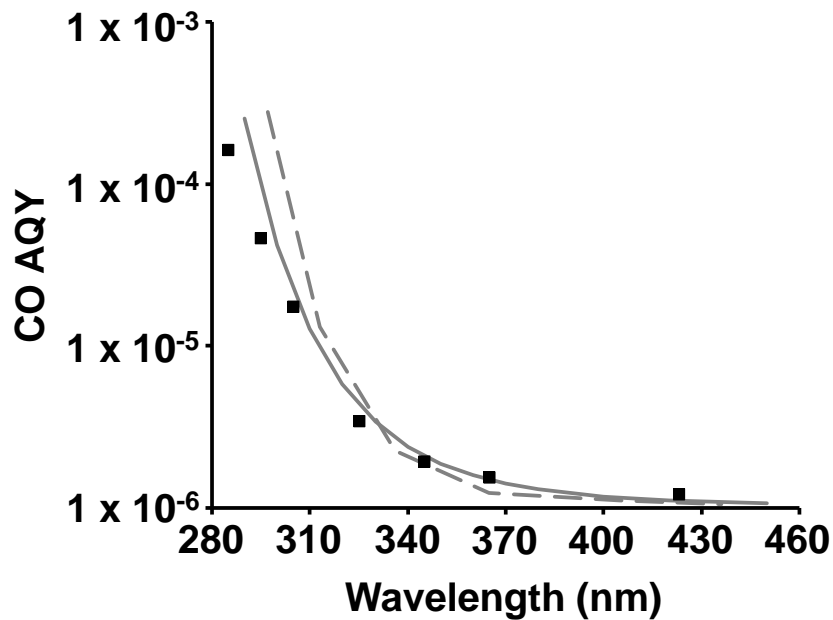

Fig. 5. Open ocean carbon monoxide apparent quantum yields (CO AQYs). Solid filled squares represent data calculated using parameters listed in the Fig. 5 legend inset together with the open ocean CDOM absorbance coefficient at $412 \mathrm{~nm}$ (absorbance data from Stubbins et al., 2006b). Other CO AQY spectra are for the Pacific Ocean (Zafiriou et al., 2003; long grey dash) and the Atlantic Ocean (Ziolkowski and Miller, 2007; solid grey line).

Table 3. Measured salinity and coloured dissolved organic matter absorbance coefficient at $325 \mathrm{~nm}\left(\mathrm{CDOM} a_{325}\right)$ in the Tyne estuary on 9 April 2001. These values were used to calculate the conservative mixing of CDOM and apparent quantum yields.

\begin{tabular}{lcc}
\hline $\begin{array}{l}\text { Station Name } \\
\text { \# in Table 1) }\end{array}$ & Salinity & $\begin{array}{c}\text { Measured } \\
\text { CDOM } a_{325}\left(\mathrm{~m}^{-1}\right)\end{array}$ \\
\hline Scotswood Bridge (1) & 0.08 & 60.1 \\
St. Peter's (3) & 1.0 & 58.7 \\
St. Anthony's (4) & 1.8 & 55.0 \\
Wallsend (6) & 6 & 49.2 \\
Howdon (8) & 7.8 & 34.7 \\
Near Howdon (9) & 10.2 & 38.5 \\
Baby Bridge (10) & 14.0 & 33.5 \\
North Shields (11) & 16.8 & 27.5 \\
Tynemouth Piers (12) & 21.8 & 19.1 \\
Tyne Plume (13) & 28.3 & 8.1 \\
North Sea (14) & 32.4 & 1.4 \\
\hline
\end{tabular}

\subsection{Modelled carbon monoxide photoproduction in the Tyne estuary}

Although the causality underlying the empirical correlation between CO AQY and CDOM $a_{412}$ remains unclear, the relationship between these two parameters offers a robust and simple proxy for the prediction of CO AQYs in natural waters. Therefore, this proxy was used to model CO AQY spectra and $\mathrm{CO}$ photoproduction in the Tyne estuary. 


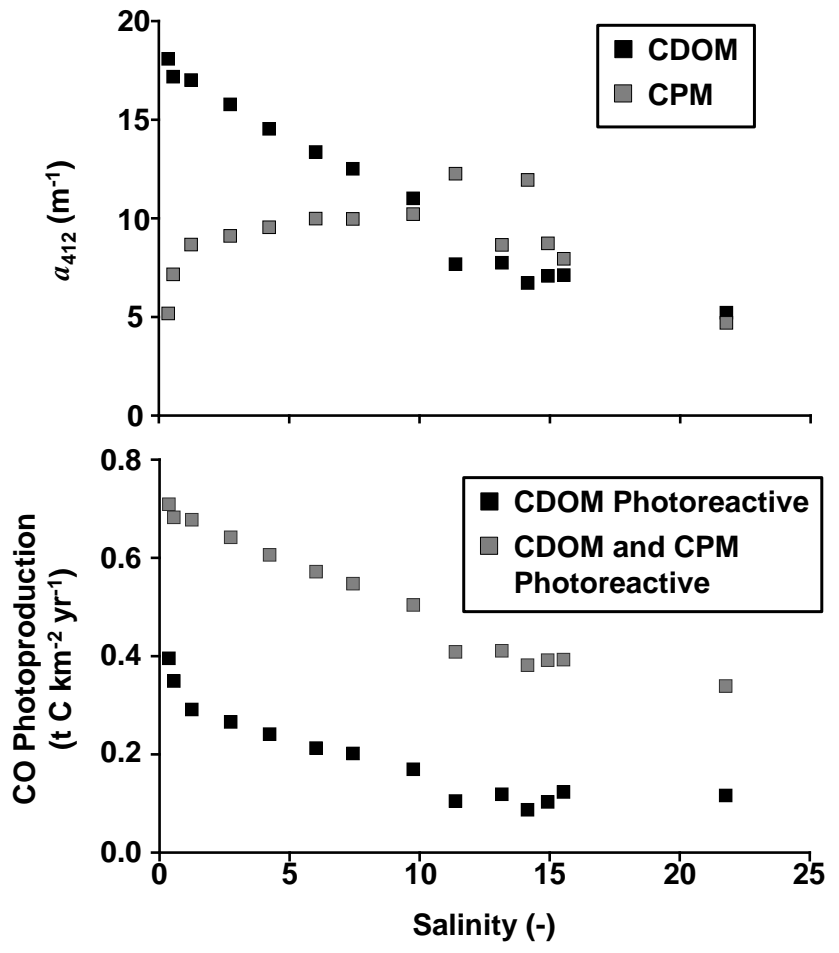

Fig. 6. Top panel: seasonally averaged coloured dissolved organic matter (CDOM; black fill) and particulate coloured material (CPM; grey fill) absorption coefficient at $412 \mathrm{~nm}$ versus salinity in the Tyne estuary. Bottom panel: seasonally averaged carbon monoxide versus salinity in the Tyne estuary. Black fill: assuming only photons absorbed by CDOM are involved in carbon monoxide (CO) photoproduction; grey fill: assuming all photons absorbed by chromophores (i.e.: CDOM plus particulates) are involved in $\mathrm{CO}$ photoproduction.

The equation and parameters described in the caption to Fig. 4 were used to calculate CO AQY spectra using annual average CDOM $a_{412}$ for sites in the Tyne estuary (Table 1). Best fit parameterisations were obtained by dividing the CO AQY spectra into two sections (285-345 nm and $345-423 \mathrm{~nm}$ ) each fitted using a power regression (Stubbins et al., 2006b). These CO AQY spectra were then used to calculate CO photoproduction via Eq. (3) (Stubbins et al., 2006b):

$$
\begin{aligned}
& \sum_{\text {Station Area }} \int_{280}^{800}{\text { (irradiance } \cdot \text { attenuation }_{1+2}} \\
& \left.\cdot A_{\mathrm{CDOM}} / A_{\text {Total }} \cdot \mathrm{CO} \mathrm{AQY}\right)_{\lambda}
\end{aligned}
$$

where irradiance is annual global spectral solar irradiance at 55 degrees north (latitude of Tyne estuary), attenuation factors 1 and 2 are corrections for the reflection of light by cloud (0.8; Nelson et al., 1998; Zafiriou et al., 2003) and the water's surface (non-spectral, 0.93; Zepp and Cline, 1977), and $A_{\mathrm{CDOM}}$ and $A_{\text {Total }}$ are the CDOM and total light absorption (optical density) in the water column. $A_{\text {Total }}$ is the total light absorption in the water column, calculated as the sum of CDOM, CPM and pure water absorbance spectra, the latter taken from Buiteveld et al. (1994). As noted in Sect. 2.3, the method employed to calculate CPM absorbance actually delivers an overestimate derived from a partially corrected measurement of particulate light attenuation. The use of this overestimate of CPM absorbance in Eq. (3) leads to an underestimation of the amount of light absorbed by CDOM in the estuary. Therefore, the rate calculated in Eq. (3) is presented as a minimum predicted $\mathrm{CO}$ photoproduction rate for the estuary.

Recent work has shown that $\mathrm{CO}$ photoproduction from CPM is approximately as efficient as $\mathrm{CO}$ photoproduction from CDOM (Xie and Zafiriou, 2009). Therefore, CO photoproduction was further calculated assuming all light entering the water column to be absorbed by photoreactive chromophores, whether particulate or dissolved (i.e. the terms $A_{\text {CDOM }}$ and $A_{\text {Total }}$ were removed from Eq. 3). This estimate provides an upper limit to $\mathrm{CO}$ production to compliment the lower limit calculated above.

Annual solar irradiance was calculated following the rationale presented in Stubbins et al. (2006b). Firstly, the average daily spectral global irradiance at 55 degrees north for the winter and summer solstices, spring and winter equinoxes, and mid points between each was generated using SMARTS2, giving a total of 8 equidistant dates. Following Stubbins et al. (2006b), seasonal variations in irradiance were graphed over the spectral range $280-800 \mathrm{~nm}$ (resolution $1 \mathrm{~nm}$ ) and the areas under the curves calculated by integration (SPSS Sigmaplot) to determine annual irradiance at each wavelength. Annual photon fluxes $\left(\mathrm{E} \mathrm{yr}^{-1}\right)$ were then determined for each Tyne estuary section, using section surface areas in Table 1, and CO photoproduction calculated following Eq. (3).

CDOM $a_{412}$, estimated CPM $a_{412}$ and rates of CO photoproduction versus salinity are shown in Fig. 6 . The $a_{412}$ data (Fig. 6, top panel) show CDOM absorbance to dominate at the head of the estuary. Downstream the proportion of light absorbed by CPM increases so that from a salinity of $\sim 10$ and onwards downstream to the mouth of the estuary light absorption at $412 \mathrm{~nm}$ by CDOM and particulates are roughly equal (Fig. 6). As a result of the CDOM and CPM distributions, the $\mathrm{CO}$ photoproduction modelled assuming only CDOM to be photoreactive falls steeply as CPM absorbance increases between salinities of 0 and 2 at the head of the estuary. Modelled CO photoproduction continues to fall until salinity $\sim 12$ and then remains constant throughout the rest of the estuary, even as CO AQYs decline. Fluctuations in $\mathrm{CDOM}$, particulate absorbance and $\mathrm{CO}$ photoproduction between salinities 10 and 16 reflect minor inputs of low CDOM, high particulate load waters from a nearby wastewater outfall (Howdon). The lower estimate of estuarine CO photoproduction based upon CDOM photoreactivity alone was 1.38 Tonnes-C $\mathrm{yr}^{-1}$. The upper limit, assuming all light entering the water column produces $\mathrm{CO}$, whether absorbed by 
CDOM or CPM, was more than twice as high (3.57 Tonnes-

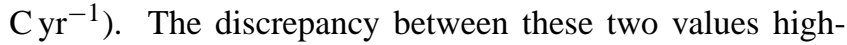
lights the need for further work to constrain the relative importance of CDOM and CPM in environmental photoreactions.

Finally, in the current study all AQYs were determined at $25^{\circ} \mathrm{C}$, whereas, temperatures in the River Tyne and its estuary ranged from $\sim 5^{\circ} \mathrm{C}$ in January to $\sim 15^{\circ} \mathrm{C}$ in August (personal observation, 1998-2001). As CO AQYs are temperature dependant, the CO AQYs measured in the current study were adjusted using the CO AQY temperature sensitivities for the waters of the upper St. Lawrence estuary (Zhang et al., 2006). CO AQYs were temperature corrected for the winter $\left(5^{\circ} \mathrm{C}\right)$, summer $\left(15^{\circ} \mathrm{C}\right)$, spring, and autumn (both $\left.10^{\circ} \mathrm{C}\right)$. The correction for the upper St. Lawrence was chosen and applied to our dataset as the St. Lawrence waters exhibited the greatest temperature sensitivity in the study of Zhang et al. (2006), increasing by $\sim 70 \%$ per $20^{\circ} \mathrm{C}$ increase. Applying the most extreme temperature correction from Zhang et al. (2006) to our CDOM-only prediction of estuarine CO production yielded a new, reduced minimum estimate of $\mathrm{CO}$ photoproduction in the Tyne estuary of 0.99 Tonnes-C $\mathrm{yr}^{-1}$.

\subsection{Photomineralization of dissolved organic carbon}

A first order estimate of total dissolved organic carbon (DOC) photomineralization in the Tyne estuary was made by extrapolating from $\mathrm{CO}$ photoproduction using a ratio of dissolved inorganic carbon:biolabile DOC:CO photoproduction of 20:13:1 (Miller and Zepp, 1995; Gao and Zepp, 1998; Miller et al., 2002). Estimated production of dissolved inorganic carbon, mineralization through photoproduction of biolabile carbon and total DOC mineralization were thus 20-71, 13-46 and 33-117 Tonnes- $\mathrm{yr}^{-1}$, respectively. Riverine DOC inputs to the Tyne estuary were estimated at $\sim 25600$ Tonnes-C $\mathrm{yr}^{-1}$ based upon an annually averaged freshwater flow rate of $55 \mathrm{~m}^{3} \mathrm{~s}^{-1}$ for the period 1998-2001 (Environment Agency, UK; http://www. environment-agency.gov.uk) and an annually averaged freshwater DOC concentration of $1230 \mu \mathrm{M}$ (Spencer et al., 2007). Using these values, estimated DOC removal through $\mathrm{CO}$ photoproduction amounts to a modest $0.004-0.014 \%$ of total DOC inputs and total photochemical losses of DOC within the estuary are similarly small: $0.13-0.46 \%$ of the DOC input.

\section{Conclusions}

A conservative mixing model involving freshwater and marine CDOM was unable to account for the large decrease in CO AQYs observed between the head and mouth of the Tyne estuary. Instead, the linear relationship between CDOM $a_{412}$ and CO AQYs provides a robust proxy for the prediciton of AQY spectra throughout the Tyne estuary. This relationship is also a robust predictor of open ocean AQYs and allows assessing CDOM photoreactivity in a water body from wavelength specific satellite ocean colour data (e.g. SeaWiFS, bandwidth 402-422 nm; MODIS, bandwidth 405-420 nm). Further work is required to determine the veracity of this approach in systems where CDOM has other sources and varying histories.

Extrapolating modelled $\mathrm{CO}$ photoproduction in the Tyne to rates of total DOC photomineralization implies a minor role for photochemistry in the C-cycle of the Tyne estuary, with less than $1 \%$ of the riverine DOC input being removed during estuarine transport. This is perhaps not surprising as the Tyne estuary $\left(\sim 55^{\circ} \mathrm{N}\right)$ is subject to moderate light levels and receives inputs of high DOC river water (average: $1230 \mu \mathrm{M}$; Spencer et al., 2007), which is rapidly exported to the coastal North Sea (average residence time: $\sim 12$ days; Watts-Rodrigues, 2003).

Measured CO AQYs fell by between $47 \%$, at $285 \mathrm{~nm}$, to $80 \%$, at $345 \mathrm{~nm}$, during transit from the head to the mouth of the estuary, with only 8 to $14 \%$ of this decrease ascribable to the mixing of high AQY freshwaters with low photoreactivity sea water. This drop in photoreactivity indicates that a highly photoreactive fraction of the CDOM pool is rapidly and preferentially lost during estuarine transit. Therefore, in estuary processes appear to have a major impact upon the photoreactivity (i.e., CO AQYs) of CDOM exported to the coastal North Sea. Previous work has shown CO AQYs to fall rapidly with irradiation time (photons absorbed; Zhang et al., 2006), indicating that the reduction in CDOM photoreactivity may be driven by in estuary CDOM photobleaching. Further quantitative modelling studies are required to determine whether photobleaching can indeed drive the drop in photochemistry observed as CDOM is exported from riverto-sea.

Acknowledgements. We would like to thank Vassilis Kitidis and Gordon Henry for their help running the irradiation system; Ali and Kate, the crew of R/V Bernicia; and the anonymous reviewers for their insightful comments and suggestions which have improved the finished article. Laboratory work was funded by the National Environmental Research Council (grant number GR3 11665), Newcastle University and Plymouth Marine Laboratory, data handling, modelling and writing were funded by the National Science Foundation (OCE-0327446 and OCE-0728634). Any opinions, findings, and conclusions or recommendations expressed in this paper are those of the authors and do not necessarily reflect the views of the funding bodies.

Edited by: T. J. Battin

\section{References}

Ahad, J. M. E., Barth, J. A. C., Ganeshram, R. S., Spencer, R. G. M., and Uher, G.: Controls on carbon cycling in two contrasting temperate zone estuaries: The Tyne and Tweed, UK, Estuar. Coast. Shelf S., 78, 685-693, 2008. 
Babin, M. and Stramski, D.: Light absorption by aquatic particles in the near-infrared spectral region, Limnol. Oceanogr., 47, 911915, 2002.

Bates, T. S., Kelly, K. C., Johnson, J. E., and Gammon, R. H.: Regional and seasonal variations in the flux of carbon monoxide to the atmosphere, J. Geophys. Res., 100(D11), 23093-23101, 1995.

Bremner, A.: The late glacial geology of the Tay Basin from pass of Birnam to Grandtully and Pitlochry, Trans. Edinburgh Geol. Soc., 13, 473-483, 1939.

Bryant, R. G. and Gilvear, D. J.: Quantifying geomorphic and riparian land cover changes either side of a large flood event using airborne remote sensing: River Tay, Scotland, Geomorphology, 29, 307-321, 1999.

Buiteveld, H., Hakvoort, J. H. M., and Donze, M.: The optical properties of pure water, in: Ocean Optics XII. SPIE Proceedings Series, Bergen, Norway, edited by: Jaffe, J. S., SPIE, Bellingham, 174-183, 1994.

Calvert, J. G. and Pitts Jr., J. N.: Photochemistry, John Wiley and Sons, New York, 1966.

Conrad, R., Seiler, W., Bunse, G., and Giehl, H.: Carbon monoxide in seawater (Atlantic Ocean), J. Geophys. Res., 87(C11), 88398852, 1982.

Del Vecchio, R. and Blough, N. V.: Photobleaching of chromophoric dissolved organic matter in natural waters: Kinetics and modeling, Mar. Chem., 78, 231-253, 2002.

Doney, S. C., Najjar, R. G., and Stewart, S.: Photochemistry, mixing and diurnal cycles in the upper ocean, J. Mar. Res., 53, 341-369, 1995.

Fichot, C. G. and Miller, W. L.: An approach to quantify depthresolved marine photochemical fluxes using remote sensing: Application to carbon monoxide $(\mathrm{CO})$ photoproduction, Remote Sens. Environ., 114, 1363-1377, 2010.

Gao, H. Z. and Zepp, R. G.: Factors influencing photoreactions of dissolved organic matter in a coastal river of the southeastern United States, Environ. Sci. Technol., 32, 2940-2946, 1998.

Helms, J. R., Stubbins, A., Ritchie, J. D., Minor, E. C., Kieber, D. J., and Mopper, K.: Absorption spectral slopes and slope ratios as indicators of molecular weight, source, and photobleaching of chromophoric dissolved organic matter, Limnol. Oceanogr., 53, 955-969, 2008.

Hope, D., Billett, M. F., Milne, R., and Brown, T. A. W.: Exports of organic carbon in British rivers, Hydrol. Process., 11(3), 325344, 1997.

Hu, C. M., Muller-Karger, F. E., and Zepp, R. G.: Absorbance, absorption coefficient, and apparent quantum yield: A comment on common ambiguity in the use of these optical concepts, Limnol. Oceanogr., 47, 1261-1267, 2002.

Kettle, A. J.: A model of the temporal and spatial distribution of carbon monoxide in the mixed layer, M.Sc. Thesis, Woods Hole Oceanogr. Inst.-Mass, Inst. of Technol, Joint Program in Oceanogr., Woods Hole, MA, 1994.

Kettle, A. J.: Diurnal cycling of carbon monoxide (CO) in the upper ocean near Bermuda, Ocean Model., 8, 337-367, 2005.

Maitland, P. S. and Smith, I. R.: The River Tay: ecological changes from source to estuary, P. Roy. Soc. Edinb., 92B, 373-392, 1987.

Miller, A. E. J.: Seasonal investigations of dissolved organic carbon dynamics in the Tamar Estuary, UK, Estuar. Coast. Shelf S., 49(6), 891-908, 1999.
Miller, W. L. and Zepp, R. G.: Photochemical production of dissolved inorganic carbon from terrestrial organic-matter: Significance to the oceanic organic-carbon cycle, Geophys. Res. Lett., 22(4), 417-420, 1995.

Miller, W. L., Moran, M. A., Sheldon, W. M., Zepp, R. G., and Opsahl, S.: Determination of apparent quantum yield spectra for the formation of biologically labile products, Limnol. Oceanogr., 47(2), 343-352, 2002.

Mopper, K. and Kieber, D. J.: Marine photochemistry and its impact on carbon cycling, in: The Effects of UV Radiation in the Marine Environment, Cambridge Environ. Chem. Ser., vol. 10, edited by: de Mora, S., Demers, S., and Vernet, M., Cambridge Univ. Press, New York, 101-129, 2000.

Mopper, K. and Kieber, D. J.: Impact of DOM Photochemistry on the Biogeochemical Cycling of Carbon, Nitrogen, Sulfur and Phosphorus in the Sea, in: Biogeochemistry of Marine Dissolved Organic Matter, edited by: Carlson, C. and Hansell, D., Academic Press, 456-503, 2001.

Moran, M. A. and Zepp, R. G.: Role of photoreactions in the formation of biologically labile compounds from dissolved organic matter, Limnol. Oceanogr., 42, 1307-1316, 1997.

Najjar, R. G., Erickson III, D. J., and Madronich, S.: Modeling the air-sea fluxes of gases formed from the decomposition of dissolved organic matter: Carbonyl sulfide and carbon monoxide, in: The Role of Nonliving Organic Matter in the Earth's Carbon Cycle: Report of the Dahlem Workshop on the Role of Nonliving Organic Matter in the Earth's Carbon Cycle, Berlin 1993, 12-17 September, edited by: Zepp, R. G. and Sonntag, C., John Wiley, New York, 107-132, 1995.

Nelson, N. B., Siegel, D. A., and Michaels, A. F.: Seasonal dynamics of colored dissolved organic material in the Sargasso Sea, Deep-Sea Res. Pt. I, 45(6), 931-957, 1998.

Preisendorfer, R. W.: Hydrologic Optics, US Dept. of Commerce, NOAA Env. Res. Lab., Washington DC, 5, 255-259, 1976.

Sholkovitz, E. R.: Chemical and physical processes controlling the chemical composition o suspended material in the River Tay estuary, Estuar. Coast. Mar. Sci., 8(6), 523-545, 1979.

Sjöberg, T. N.: The distribution and cycling of dissolved carbon monoxide in estuarine, coastal and shelf break environments, Ph.D. thesis, Univ. of East Anglia, UK, 1999.

Spencer, R. G. M., Ahad, J. M. E., Baker, A., Cowie, G. L., Ganeshram, R., Upstill-Goddard, R. C., and Uher, G.: The estuarine mixing behaviour of peatland derived dissolved organic carbon and its relationship to chromophoric dissolved organic matter in two North Sea estuaries (U.K.), Estuar. Coast. Shelf S., 74, 131-144, 2007.

Stubbins, A.: Aspects of aquatic CO photoproduction from CDOM, Ph.D. Thesis, University of Newcastle-upon-Tyne, UK, 2001.

Stubbins, A., Uher, G., Kitidis, V., Law, C. S., Upstill-Goddard, R., and Woodward, E. M. S.: The open ocean source of atmospheric carbon monoxide, Deep-Sea Res. Pt. II, 53, 1685-1694, 2006 a.

Stubbins, A., Uher, G., Law, C. S., Mopper, K., Robinson, C., and Upstill-Goddard, R. C.: Open ocean carbon monoxide photoproduction, Deep-Sea Res. Pt. II, 53, 1695-1705, 2006 b.

Stubbins, A., Hubbard, V., Uher, G., Aiken, G., Law, C. S., UpstillGoddard, R. C., and Mopper, K.: Relating carbon monoxide photoproduction to dissolved organic matter functionality, Environ. Sci. Technol., 42, 3271-3276, 2008.

Uher, G., Hughes, C., Henry, G., and Upstill-Goddard, R. C.: 
Non-conservative mixing o colored dissolved organic matter in a humic-rich, turbid estuary, Geophys. Res. Lett., 28(17), 33093312, 2001.

Valentine, R. L. and Zepp, R. G.: Formation of carbon-monoxide from the photodegradation of terrestrial dissolved organic-carbon in natural-waters, Environ. Sci. Technol., 27, 409-412, 1993.

Watts-Rodrigues, P.: Modelling nitrous oxide production in two contrasting British estuaries: The Forth and the Tyne, Ph.D. thesis, University of Newcastle-upon-Tyne, UK, 2003.

White, E. M., Kieber, D. J., Sherrard, J., Miller, W. L., and Mopper, K.: Carbon dioxide and carbon monoxide photoproduction quantum yields in the Delaware Estuary, Mar. Chem., 118, 1121, 2010.

Xie, H. and Zafiriou, O. C.: Evidence for significant photochemical production of carbon monoxide by particles in coastal and oligotrophic marine waters, Geophys. Res. Lett., 36, L23606, doi:10.1029/2009GL041158, 2009.
Xie, H., Belanger, S., Demers, S., Vincent, W. F., and Papakyriakou, T. N.: Photobiogeochemical cycling of carbon monoxide in the southeastern Beaufort Sea in spring and autumn, Limnol. Oceanogr., 54, 234-249, 2009.

Zafiriou, M. C., Andrews, S. S., and Wang, W.: Concordant estimates of oceanic carbon monoxide source and sink processes in the Pacific yield a balanced global "blue-water" CO budget, Global Biogeochem. Cy., 17(15), 15-13, 2003.

Zepp, R. G. and Cline, D. M.: Rates of direct photolysis in aquatic environments, Environ. Sci. Technol., 11, 359-366, 1977.

Zhang, Y., Xie, H., and Chen, G.: Factors affecting the efficiency of carbon monoxide photoproduction in the St. Lawrence estuarine system (Canada), Environ. Sci. Technol., 40, 7771-7777, 2006.

Ziolkowski, L. A. and Miller, W. L.: Variability of the apparent quantum efficiency of $\mathrm{CO}$ photoproduction in the Gulf of Maine and Northwest Atlantic, Mar. Chem., 105, 3-4, 2007. 